\title{
A Noble Residence for a Female Regent: Margaret of Austria and the 'Court of Savoy' in Mechelen
}

Dagmar Eichberger*

This chapter investigates the principal residence, the 'Court of Savoy', of Archduchess Margaret of Austria (1480-1530), governor-general and regent of the Burgundian-Habsburgian Netherlands (Fig. 1.1). ${ }^{\prime}$ Margaret of Austria is the first of a series of female regents who resided and ruled in this economically important part of the Holy Roman Empire. ${ }^{2}$ Margaret's residence in Mechelen was one of the most significant princely courts in the early sixteenth-century Netherlands, which attracted the attention of humanists, international diplomats and artists alike.

This chapter examines the ways in which Margaret of Austria's social rank and gender had a particular impact on the edifice itself or on the interior decoration of her residence. The first part of this study looks closely at the architectural structure of the so-called 'Court of Savoy' (Fig . 1.2) and the built environment surrounding the residence. Particular attention is paid to the living quarters inhabited by the widowed archduchess and to her garden. The second part of this chapter analyses how Margaret of Austria organized and interpreted these spaces by carefully furnishing her rooms with a large variety of objects and artefacts. It argues that her identity as a female regent is clearly reflected in the way in which she decorated her residence.

When Margaret of Austria returned from the Duchy of Savoy to the Low Countries in October 1506, she established her permanent residence in the city of Mechelen. While her forebears, the dukes of Burgundy, had resided in princely residences in Brussels, Bruges, Ghent, Lille, Hesdin and Arras, she chose to live in the city where her close relative and foster mother, Dowager-Duchess Margaret of York (1446-1503), had spent the last thirty years of her life. ${ }^{3}$ Margaret of Austria took over her foster mother's last apartment and her private oratory at the old St Peter's church and integrated them both into her new residence.

The city of Mechelen, which was also the seat of the Great Council, was 
eager to become the new centre of political activities. The town council therefore offered to pay for the erection of a new residence worthy of a highranking court with international connections. The burghers of Mechelen hoped that the presence of such a court would bring trade and prosperity to their community. ${ }^{4}$

\section{The construction of the 'Court of Savoy'}

The site chosen for the erection of Margaret of Austria's 'Court of Savoy' was situated opposite the so-called 'Court of Austria' or 'Court of the Emperor'. This spacious fifteenth-century mansion on Keizerstraat had been given to Maximilian by the city of Mechelen as a residence for his grandchildren, the young prince Charles (1500-58) and three of his sisters. In 1507, Maximilian acquired several houses in the vicinity of the 'Court of Austria' from his treasurer-general Hieronymus Lauwerijn in order to secure a large block of land for the future domicile of his only daughter. ${ }^{6}$ Margaret's future residence was to be framed in the north by Keizerstraat and in the south by Voochtstraat. The other two sides of the precinct bordered on to the medieval St Julian's Hospital on its eastern and the old St Peter's church on its western side. The churchyard was separated from the new residence by a narrow road called Korte Magdenstraat. ${ }^{7}$ My reconstruction of the rooms on the first floor of the western wing (Figs 1.3 and 1.4) is based on the earliest existing floor plan of the "Court of Savoy's as well as on written and visual documents.

Construction of three wings which constituted Margaret of Austria's residence began in 1507, but the residence was still unfinished twenty-three years later when the archduchess died unexpectedly at the age of fifty. The task of planning and execution of Margaret of Austria's official seat of government was entrusted to three members of the Keldermans family, one of the foremost families of architects and entrepreneurs in the BurgundianHabsburgian Netherlands. ${ }^{9}$

Anthonis Keldermans I (d. 1512), city architect of Mechelen, and his son Anthonis II (d. 1515) were responsible for the first building phase of the 'Court of Savoy' between 1507 and 1515. Their first priority was to construct comfortable living quarters and the necessary administrative areas for the regent and her sizeable household. For economic reasons, the Keldermans made use of extant structures, particularly a long row of smaller houses along Korte Magdenstraat. These older structures are still recognizable today (rooms $\mathrm{D}$ to $\mathrm{J}$ ), as the difference in width and height of the individual segments was not harmonized by the Keldermans. The older houses were integrated into the newly formed western wing of Margaret's residence. There is thus a marked difference between the regular and grander elevation facing 
the inner courtyard $(\mathrm{B}, \mathrm{C}, \mathrm{K}, \mathrm{L})$ and the irregular and unassuming elevation facing Korte Magdenstraat. Up until the late eighteenth century, this irregularity was partly concealed by the church of St Peter, which occupied the site on the opposite side of the narrow lane.

The southern wing on Voochtstraat (Fig. 1.6) with its tall new house on the corner of Korte Magdenstraat (nieuw huys), the spacious entrance gate (a), and the large staircase (b) was an entirely new construction. The architectural style in which it was built was less of a compromise and represented the residence's outer front, while the principal façade and entrance gate on Keizerstraat were still under construction.

In 1515, soon after the death of Anthonis I and Anthonis II, Rombout II Keldermans (c. 1460-1531) assumed the role of city architect. In the following years, Rombout drew up additional plans for the "Court of Savoy" 10 and started work on the northern section of the residence. This part of Margaret's residence comprised the great hall $(K)$, the new audience chamber (L) and the modern stone façade with a second entrance gate on Keizerstraat (Figs 1.2 and 1.3).

The floor plan (Figs 1.3 and 1.4) suggests that the architect initially intended to provide two main entrance-ways into the residence, one for the members of the household (a) and one for visitors who did not require to proceed to the inner parts of the residence (d). As the audience chamber and the festive hall residence were not operational during Margaret's lifetime, this division between the official rooms in the north and the sections with limited access in the southern and western wing was never put into action. Instead, Margaret had to organize her daily life within the parameters of the completed sections of her residence."

We do not know why the city made no stronger effort to complete the two large halls $(\mathrm{K}, \mathrm{L})$, which would have given the residence a grander appearance. The city of Mechelen may have held the view that a small residence the size of a middling urban palace would be sufficient for Margaret of Austria, as her family still had the Coudenberg palace in Brussels at their disposal. Important events, such as the coronation festivities for Charles $\mathrm{V}$, were held in this older, more spacious and more prestigious Burgundian residence. Mary of Hungary, who took over the regency after the death of her aunt, soon turned her back on Mechelen and moved to Brussels, where she was given new rooms and a large festive hall in the Coudenberg palace. 


\section{Margaret of Austria's living quarters and their location within the residence}

While parts of the original building structure were altered by later occupants, the suite of rooms once inhabited by Margaret of Austria can be identified (Fig. 1.5). ${ }^{12}$ My proposed reconstruction (Fig. 1.4) is based on early floor plans (Fig. 1.3), the existing building structure, Margaret's detailed inventories, the yearly accounts of the city of Mechelen, and a large set of watercolours by the nineteenth-century artist Auguste van den Eynde..$^{13}$ The contents of the individual rooms indicated in the inventories yield valuable insights into the ways individual rooms were used. A contemporary court ordinance of 1525 sheds light on the rules and regulations of everyday life, which were intricately tied to the various spaces within the residence. ${ }^{14}$

As long as the main entrance on Keizerstraat was still under construction, visitors had to enter the residence from Voochtstraat (a) (Fig. 1.6). After passing through a portico made from bluestone, one could reach the first floor via a wide, two-aisled staircase with two large tracery windows (b). The upper landing provided access either to a large hall with a small apsidial window (A) or to a spacious chamber facing the southern courtyard (B). ${ }^{15}$ The large hall can be identified as the former court chapel or chappelle. ${ }^{16}$ Room $\mathrm{B}$ is identical with the premiere chambre à chemynée and contained Margaret's official portrait gallery. It also served as her large dining room. ${ }^{17}$

Beyond the official dining hall was the seconde chambre à chemynée $(\mathrm{C})$, Margaret's multifunctional bedroom..$^{18}$ Adjacent to Margaret's most personal chamber was her petit cabinet or study $(E)$. This small cabinet housed some of Margaret's personal belongings, especially small collectible items and writing utensils. The description in the inventory (1523-24) suggests that this cabinet was located next to the walkway (G) which connected Margaret's bedroom with a private oratory on the other side of Korte Magdenstraat. ${ }^{19}$ This double-storied oratory was attached to the chancel of the old parish church of St Peter. The walkway and the private oratory had initially been constructed for the ageing duchess, Margaret of York, after her retirement to one of Hieronymus Lauwerijn's houses on Korte Magdenstraat. Margaret of Austria lived the solitary life of a devout widow, quite similar to that of the old dowager-duchess, who remained a single woman for the last twenty-six years of her life. It was, in all likelihood, Margaret of Austria's own decision to occupy the bedroom and oratory which had been used by her close relative and foster mother until 1503.

Religious life could take many different forms at the court of Margaret of Austria. In her court chapel, she employed a priest for performing mass; in her bedroom she installed an altar-like structure for her private devotions; and on the other side of Korte Magdenstraat she actively used the private oratory 
attached to her parish church. ${ }^{20}$ Private oratories of that kind were quite common in the late Middle Ages and were popular with men and women alike. ${ }^{21}$ Such oratories allowed the inhabitant to attend a mass without leaving their residence. Men and women of high social standing wished to be able to pray in relative privacy, that is, without being watched by the general public. A recently discovered eighteenth-century drawing by Dirk Verijk gives us a lively impression of how the wooden bridge once connected Margaret's residence with the neighbouring church (Fig. 1.7). ${ }^{22}$ The fact that this bridge remained intact until the late eighteenth century suggests that it continued to be used by later occupants.

Most of Margaret's gold and silver plate was kept in a room described in the civic accounts as camere vanden jouweelen or 'jewellery chamber' ${ }^{23}$ For reasons of safekeeping, precious objects were kept in the room with the strongest walls, a veritable strong chamber $(\mathrm{H})$. This room could also be reached from the walkway $(\mathrm{G})$ connecting the bedroom with the oratory. ${ }^{24}$

Along Korte Magdenstraat, there were a number of smaller rooms or cabinets which formed part of Margaret's living quarters. The two spaces which were connected to the small spiral staircase on Korte Magdenstraat functioned as alternative passage-ways from one story to the other $(\mathrm{I}, \mathrm{J})$. This staircase was used by Margaret's ladies-in-waiting, who occupied a number of spacious and well-lit rooms on the second floor. In the Flemish accounts, there is also mention of a 'dressing room of Milady' (garderobbe van my vrouwen), most likely a room for keeping Margaret's clothing and linen, perhaps identical with the cabinet adjacent to Margaret's bedroom and study (F)..$^{25}$

The inventory of 1523-24 mentions another small room, the riche cabinet (D), which housed a choice of valuable artefacts such as a large silver chandelier, a gilded wooden tower and a small foldable table from Spain with coats of arms and rich silver ornaments. The baldachin made from green and white silk, embroidered with the letters ' $\mathrm{M}$ ' and ' $\mathrm{a}$ ' (Marguerite d'autriche), and two chairs suggest that the riche cabinet was used as an intimate reception room by the regent. ${ }^{26}$

The most interesting piece of decoration in the riche cabinet was a valuable diptych with an elaborate silver frame ornamented with Margaret's coats of arms, angels and enamelled daisies. This rich silver frame had been commissioned by Margaret in 1527, for displaying twenty highly treasured panel paintings by Juan de Flandes. These panels had initially belonged to Queen Isabella of Castile, her first mother-in-law. ${ }^{27}$ The furnishing of this room suggests that Margaret wished to be seen as a female leader who emanated magnificence and, at the same time, had a discerning taste in art. The paintings by Juan de Flandes were displayed for several reasons. The diptych as well as the small table stressed her close dynastic links with the Spain which now 
belonged to the house of Habsburg. The artistic quality and the religious content of the diptych both appealed to Margaret. The panels commissioned by Isabella of Castile represented a programme which was designed specifically for a female patron, as there is a strong emphasis on biblical scenes in which Christ meets and interacts with women..$^{28}$ The fact that Margaret relocated these panels from the cupboard of her bedroom to her small reception room is a clear expression of her high appreciation of this particular object.

The reconstruction of Margaret's personal apartment on the first floor of the western wing has shown that the regent had two large rooms and several small cabinets at her disposal, in which she could conduct her daily business and also devise an environment suitable for herself and her court. Margaret worked creatively with the limited space made available to her by occasionally refurbishing her rooms and by adding a new cabinet to the core unit. The large reception room and the festive hall were intended to give Margaret's residence a grander appearance, but were not completed during her lifetime.

\section{Margaret of Austria's 'garden cabinet' or 'coral cabinet'}

The most remarkable cabinet within Margaret's residence was her cabinet emprès le jardin also called the "cabinet where there are the corals [and] all things made from silver'. ${ }^{29}$ It is thus characterized by its location as a 'garden cabinet' and by its most exotic and most valuable contents, as a 'coral and silver cabinet'. This cabinet contained a large variety of items, including paintings, small-scale sculptures, embroidered images, clocks, astrolabes, games, mirrors, and so on. ${ }^{30}$ Margaret kept only a single manuscript in this room, Jean Lemaire de Belges's allegorical treatise called La Couronne Margaritique..$^{31}$ Lemaire had been Margaret's court poet and historian until $1511 .^{32}$ The 'garden cabinet' was set up by Margaret of Austria sometime after 1516 as an extension to her small study upstairs which must have proved too small for all the treasures which Margaret had accumulated over the years. ${ }^{33}$ The new 'garden cabinet' served the sole purpose of displaying 248 valuable artefacts, rarities and curiosities. ${ }^{34}$

The corals are of particular interest, as they represent one of the most modern components of Margaret's collection and carried specific significance for the regent herself..$^{35}$ Margaret owned close to fifty branches of uncarved coral and a small number of religious figurines made from the same material. The coral branches were part of a larger group of rare materials in the garden cabinet and the study upstairs, which can be categorized as Naturalia. Contemporary collectors such as Lorenzo de Medici and Isabella d'Este are also known to have owned natural objects. ${ }^{36}$ The corals, shells, precious 
stones, pearls, gold and silver ore in Margaret's collection demonstrate the growing interest in nature in its raw form. Such Naturalia and rarities were often seen as a reflection of the great abundance and diversity in the universe. ${ }^{37}$

Precious stones and corals were also imbued with symbolic qualities, which were discussed and explored in contemporary literature. Lemaire's panegyric poem La Couronne Margaritique, dating from 1504/5, describes the fashioning of a symbolic crown for the recently widowed Margaret of Austria ${ }^{38}$ The crown is decorated with representations of ten different virtues and ten precious stones. The initials of each virtue and stone correspond to one letter in the French name $M-A-R-G-U-E-R-I-T-E$. Lemaire correlates the letter ' $G$ ' with the virtue grace, or 'mercy', and the precious stone Gorgonia, or coral ${ }^{39}$ In Lemaire's text, the coral is described as a stone which provides protection against the perils of the sea, dangerous winds and nightmares and also has certain medical properties. He continues to explain that both the virtue of mercy and the coral are most suitable attributes for Margaret of Austria, as she is an outstanding princess who has been chosen by God. By placing Lemaire's manuscript in the same room as her corals, Margaret of Austria offers an interpretation for the coral branches which goes beyond a general interest in natural history and the macrocosm. Lemaire's manuscript provides an allegorical account of Margaret's momentous life and her noble character. It also contains a passage in which the author talks about the leading artists of his time, many of whom were represented in the regent's collection..$^{* 0}$ Margaret thus created layers of meaning which are specifically tailored to herself as the owner of the cabinet.

The 'coral cabinet' has been described as a space on the ground floor of the residence in which its owner demonstrated her strong interest in collecting and displaying objects of artistic, material and scientific value. This room, which was not used for any other purpose, must have played a significant role in shaping Margaret's public identity as a cultured and discerning patron of art and literature.

\section{The garden - a female metaphor?}

The garden (c) was situated away from the street, in the inner courtyard of Margaret's residence (Fig. 1.4 and 1.5). ${ }^{41}$ Margaret instructed her gardeners to plant flowers, herbs and vines. There was also a well for water. The vines formed shady arbours or covered walkways. Judging from the sparse evidence that we have, Margaret's garden was more than a utilitarian kitchen garden. Indeed, in summer, Margaret occasionally dined outdoors. She may well have used it for promenading, reading and conversing within the sheltered walls of 
her residence. The garden was added to her residence as an embellishment to and an extension of the architectural structures. In my view, it can also be seen as an expression of her interest in controlled nature. Since the turn of the century, the cultivated garden had developed into an important feature of contemporary court culture north of the Alps. ${ }^{42}$ Margaret must have been aware of this trend, which not only affected the French châteaux in the Loire valley but also had an impact on her nephew, Charles V. ${ }^{43}$ Margaret's decision to set up a cabinet with Naturalia in the immediate vicinity of the garden can be understood as an enlightened response to this general trend.

Illuminated French and Flemish manuscripts give some indication of the appearance of well-tended gardens in the fifteenth and early sixteenth centuries." In Margaret of Austria's exquisitely illuminated edition of Boccaccio's Theseida we find an illustration of an idealized enclosed garden in the vicinity of a noble residence (Fig. 1.8). ${ }^{45}$ Emilia, the beautiful sister of the amazon Hippolyte, sits on a grassy bench, weaving a garland of white and red roses. She is surrounded by green arbours, blooming rose bushes and varied flower beds. Margaret kept this manuscript in her study upstairs, which suggests that she had a particular interest in this exquisitely illuminated manuscript.

A full-page calendar miniature from the Hennessy Hours represents a realistic example of an early sixteenth-century residence with garden (Fig. 1.9). The mansion in the background has several features in common with the newly constructed southern wing of Margaret of Austria's palace in Mechelen. The motif of an upper-class couple supervising the cultivation of their private garden in spring is a new motif in calendar illustrations and reflects the growing concern for well-kept gardens in Flemish society. ${ }^{46}$ In earlier calendar illustrations the nobility had been portrayed as taking pleasure from nature in a variety of ways, for example riding out on horseback, collecting flowers, hunting in the forest, and so on. In the calendar scene from the Hennessy Hours the owner of the residence takes on a more active role as he controls the appearance of his own garden. The garden is thus a microcosm of nature shaped by the patron himself.

Late medieval gardens are commonly imbued with Marian symbolism as certain plants and architectural components were linked closely to the theological concept of the 'hortus conclusus' or enclosed garden. ${ }^{47}$ The fountain, the well, the rosebush, the lily are frequently employed to characterize Mary's immaculacy, her virginity, her modesty and her piety. These values correspond closely to women's prescribed role in early modern society as defined, for instance, by Juan Luis Vives in his treatise $D e$ institutione feminae Christianae (1524).8 If the most prominent space assigned to women was inside the house, a sheltered garden can be seen as a safe and contained extension to such interior spaces. In Mechelen, Margaret 
not only had to safeguard her own reputation, but also had to watch over the behaviour of the young girls and women who belonged to her household. The 'enclosed garden' allowed Margaret's nieces, her maiden-of-honour and her ladies-in-waiting to spend time outdoors without leaving the sheltered milieu of her residence. The garden of the 'Court of Savoy' can thus be interpreted as an environment which was well suited for an educated lady of high moral standing and contributed positively to Margaret of Austria's public profile as a caring and responsible head of a chaste household.

Unlike most other women, Margaret was not restricted to her garden to experience nature and the open countryside. We know that as a young woman she greatly enjoyed hunting. In Mechelen, she cultivated the unusual habit of riding out by herself. ${ }^{49}$ Her role as regent of the Netherlands gave her plenty of opportunities to travel through her provinces, to visit important cities and noble estates. The fact that she presented herself to the public as a pious and unwavering widow made it easier for her to conquer these domains, which were traditionally reserved for men..$^{\circ}$

When Isabella d'Este's new apartment was constructed on the ground floor of the ducal palace in Mantua during the first decade of the sixteenth century, a very private, walled-in garden with an arcade adjoined her camerini and her collection cabinets. ${ }^{51}$ Margaret of Austria's garden was not nearly as secluded from the outside world as Isabella's giardino secreto. In Margaret's case, the garden was linked to the street via the southern entrance gate. Visitors and members of the household had to pass by the garden when they entered her residence. The garden could be accessed via the main staircase and probably also by a door close to the 'garden cabinet'. The explicit link between the cabinet emprès le jardin, Margaret's main collection cabinet, and the cultivated courtyard suggests that the regent consciously extended the private sphere of her residence into her garden. By placing her corals and shells in close vicinity to the garden, Margaret may have also responded to an important Renaissance concept which regarded a private collection as a representing of 'microcosm in macrocosm'. The conspicuous connection between inside and outside thus had not only practical but also symbolical connotations.

\section{The 'Court of Savoy' - a residence for a female regent?}

Margaret of Austria's official residence was constructed by the city of Mechelen to cater for her position as the newly appointed governor-general of the Burgundian-Habsburgian Netherlands. In 1509 Margaret was promoted from governor-general to the more powerful position of regent. The question arises whether the 'Court of Savoy' reflected the fact that the head of the household was a widowed woman. 
The reconstruction of Margaret's residence makes clear that her personal living quarters consisted of two lange rooms (première chambre, seconde chambre), three smaller rooms (riche cabinet, petit cabinet, cabinet emprès le jardin), a garderobe and a private oratory located next to the St Peter's church. These rooms were complemented by a library, a court chapel and a treasure chamber. A great hall and an additional audience chamber were under construction. Let us now consider what such accommodation represented socially.

Krista De Jonge's investigation of Netherlandish residences and Burgundian court ritual has shed light on living standards for leading members of the imperial family..$^{52}$ De Jonge distinguishes between two alternative sizes of accommodation: a small suite of rooms (three rooms) and a more commodious setting (four rooms). As far as the number of rooms and the spatial arrangement were concerned, no significant difference existed between male and female members of the imperial family. The need for specific rooms such as a large dining room, a stately bedroom or a studiolo was dictated by the elaborate Burgundian court ritual which had been developed in the second half of the fifteenth century..$^{53}$

The simple version of a residential suite consisted of a formal dining room (salle à manger), a bedroom (chambre à coucher) and a study (retraite). The more elaborate arrangement consisted of the basic module plus one additional chamber. The second model provided the head of the household with more privacy, as greater distance lay between the formal dining 'room and the master bedroom. The existing evidence suggests that women were not treated differently from men if they held a sufficiently high position at court, such as queen or regent. ${ }^{54}$ Rank was more important than gender whenever a city provided space for a visiting sovereign or a resident regent. In 1517, the city of Tordesillas made arrangements for housing the young Prince Charles. The newly appointed king of Castile was offered a hall decorated with tapestries, two large rooms and a cabinet. ${ }^{55}$ The layout of Margaret of Austria's residence in Mechelen also consisted of two chambers plus one study. She had one additional small room, the riche cabinet, at her disposal and later added a second cabinet, the cabinet emprès le jardin, to the basic module.

It is noticeable that when plans were drawn up for Margaret's living quarters at her monastery in Brou, Margaret opted for the second model, which was more spacious than her accommodation in Mechelen (Fig. 1.10). The monastic buildings adjacent to the church of St Nicolas-de-Tolentin were erected between 1506 and 1512, approximately at the same time as her residential wing in Mechelen..$^{56}$ Margaret's princely suite in Brou was located on the first floor of the northern cloister and consisted of three, rather than two, large rooms, plus a small, oblong cabinet. In her convent, all rooms were 
arranged in a linear sequence so that, in accordance with contemporary court etiquette, one could proceed from more public to more private spaces. ${ }^{57}$

The layout of Margaret's personal suite corresponds to the commodious set-up described above. The largest of all three rooms (a) was located next to a grand hall (e), which had five window bays on its northern wall (first cloister) and six on its southern wall (second cloister)..$^{58}$ The size and location of room (a) suggest that it was conceived as Margaret's formal dining room. Adjacent to the first room there was a small, subdivided cabinet (b) ${ }^{59}$ which was followed by two middle-sized rooms $(c, d)$. The last room (d) was fitted with a fireplace and a small rectangular niche with a groin vault, presumably Margaret's bedroom with an in-built oratory for private devotions. Her bedroom was located closest to the passage-way (f) which led directly to Margaret's double-storied chapel at the eastern end of the church of St Nicolas-de-Tolentin.

Compared to the residential wing in Brou, the layout of the regent's apartment in Mechelen was more modest in size. At the 'Court of Savoy' Margaret of Austria had only two large rooms at her disposal. While provisions were made, probably in 1515 , for a large hall with six window bays $(\mathrm{K})$, Margaret was never in a position to use this section of her residence. The new audience room (L) equally remained unfinished. In Mechelen Margaret clearly had little success in convincing the city of the urgency of executing Rombout Keldermans's master plan. As the construction was paid for by the city council, she had to accept the pace at which the city proceeded with the construction. The Augustinian church and monastery, on the other hand, were built entirely at Margaret's own expense and completed in a short period of time. Once the regent had moved into the southern half of her Mechelen residence and managed to conduct her daily operations within the rooms allotted to her, the city lost its impetus and was no longer eager to turn the 'Court of Savoy' into a stately residence of grander dimensions.

When Margaret decided on the design for her accommodation in Brou, she must have thought she would spend her last years in this monastery..$^{60}$ She prepared for an aristocratic lifestyle which could keep up with the European courts she had been to or heard of. While the architectural complex in Brou is located far from the main centres of power, it must be seen as a project which emerged in competition with other royal projects, in particular those undertaken by Anne de Bretagne. ${ }^{61}$ In 1510 Margaret states that the tombs should be 'rich and sumptuous, in a manner befitting for a prince or a princess' ${ }^{62}$ In January 1511 , Perreal, then her architect-in-charge, explains his high expenses by comparing Margaret's majestic project favourably with the 'modest' tomb commissioned by her arch-rival Anne. Soon after, Lemaire reports from Tours that the king and queen of France were both so impressed by Colombe's clay models for Margaret's tombs that the project has to be 
described as 'le plus grand chief-d'euvre qu'on faira es parties par deça' . 63 The imposing tombs erected by Lodewijk van Boghem and Conrad Meit confirm that Margaret was an ambitious patron. Following her father's notion of artistic patronage, she clearly wanted to be remembered by a distinguished monument, which she commissioned for herself and in memory of her late husband, Philibert of Savoy.

Not only the noble tombs but also Margaret's festive hall and her living quarters in Brou were planned with her peers in mind. The large hall in Brou, measuring $8.5 \mathrm{~m}$ by $27 \mathrm{~m}$, had courtly dimensions. ${ }^{64}$ Margaret's decision to build a large palatial section into the monastery in Brou was not inspired by French or Netherlandish models. The idea of a convent palace refers back to a distinctly Spanish custom which existed long before the construction of the Escorial. This tradition can be found in the royal foundations of Toledo, Granada and Avila. ${ }^{65}$ In the Dominican monastery of Santo Tomás in Avila we can observe the same disposition as in Brou: three courtyards flank the church; the royal hall extends on the first floor along two sides of the biggest courtyard. ${ }^{66}$ Santo Tomás was a particularly important foundation both for the Spanish king and queen and for Margaret of Austria. Juan of Castille, their son and Margaret's first husband (d. 1497), was buried in one of the richest chapels of this church. Margaret not only donated large sums of money to this Spanish monastery; she also copied the basic idea for the church and convent she commissioned herself. As it happened, Margaret never returned to Brou and her stately rooms never fulfilled their envisaged grand functions."

The evidence gleaned from the analysis of her apartments in Brou and Mechelen leaves no doubt that Margaret enjoyed a high standard of living. She clearly saw space as one important criterion for projecting political and social significance. Brou was the place where she could present herself in the best possible light. This leaves us with the question why Margaret of Austria accepted the limitations imposed on her by the specific situation in Mechelen. She probably acceded to the unsatisfactory nature of a half-finished residence in Mechelen because she did not want to be perceived as self-important or vainglorious by her native citizens. As far as the outer appearance of the 'Court of Savoy' was concerned, it projected an image of economy rather than of splendour. In Mechelen, Margaret's principal objective was to further the political interests of her family. ${ }^{67}$ Here she did not aim at building an architectural monument to herself and there is no evidence that she ever contributed financially to the construction of the 'Court of Savoy'. In Mechelen, all her energies went into furnishing the rooms in which she lived on a daily basis. Only inside the walls of her residence did she provide visual clues and information about herself as the resident ruler. 


\section{Margaret's library - 'una libreria per donne assai ornata et riccha'}

The architectural framework of Margaret of Austria's residence in Mechelen may not have been the largest and most magnificent in the BurgundianHabsburgian Netherlands, but the regent made strenuous efforts to improve the appearance of the 'Court of Savoy' by turning her attention to the decoration of the principal rooms inside her residence. The inventories of 1516 and 1523-24 reveal that, over the years, Margaret built up a considerable collection of artefacts, Naturalia and Exotica, including approximately 380 manuscripts and printed books, 176 paintings, 130 tapestries, 7 embroidered images, 52 sculptures and 46 objects made from gold, enamel and precious stones. The care with which the regent administered her residence and her valuable collection of movable objects was remarked upon by the Italian diplomat Antonio de Beatis, who visited Margaret's residence in 1517:

At Mechelen one sees the house of Madame Margaret, which is very beautiful and ordered, although it does not have much of a view, where there is a very ornate and well-stocked library for women ... And there are beautiful paintings and other varied pictures and all in a good hand. And in marble there is the head of the duke of Savoy, her deceased husband, who is shown as a very handsome young man, as he is said to have been, and of her Serene Highness herself, when she was young, done with great skill and of naturalistic proportions. ${ }^{68}$

Of particular interest here is de Beatis's reference to the 'very ornate and well-stocked library for women'. There are two ways in which his remarks can be understood. Either de Beatis refers to the contents of the library or he alludes to the way in which the library was decorated. Both readings are possible, but only one stands up to closer scrutiny. Margaret's substantial collection of books, which contained manuscripts on chivalric romance, history and philosophy, as well as devotional books, cannot be described as a typically female library. Margaret owned many books which were not considered suitable reading material for women by such authorities as Juan Luis Vives. ${ }^{69}$ Notably, while the contents of her library challenged some more conservative views on gender, certain aspects of its decoration were deliberately gender-specific.

Significantly, Margaret turned her library into a public memorial to her late husband, Philibert of Savoy (Fig. 1.11). Next to the marble busts of young Margaret and Philibert, the regent hung two painted portraits of Philibert and placed his complete armour on a metal stand. The inventory of 1516 mentions an epitaph for Duke Philibert of Savoy, mounted on a small wooden panel. ${ }^{70}$ In public, Margaret consistently presented herself either as a dutiful widow or as the wife of Philibert of Savoy. She was addressed by her subjects as 
'Milady from Savoy'; her residence was called the 'Court of Savoy'. Margaret considered it important to demonstrate publicly her unwavering loyalty towards her last husband. ${ }^{{ }^{1}}$ Like many other women at her time, Margaret felt obliged to define herself in relation to a male consort. Apart from fulfilling the prevalent expectations of a dutiful wife, Margaret probably also adopted this attitude to protect herself from being remarried a fourth time at the expressed wish of her father and her brother.

Only towards the end of Margaret's life can we observe the development of two alternative modes of representation. In a portrait medallion by Conrad Meit dating from 1528 she is presented as the 'only daughter and aunt of the Austrian emperor'. ${ }^{72}$ Her prominent place in the Habsburg dynasty is also stressed in the illuminated genealogy which she commissioned around $1527 .^{73}$ In the late $1520 \mathrm{~s}$, it may have been politically more significant for Margaret to be known as a member of this powerful family than as the wife of the late duke of Savoy.

A more allegorical mode of representation can be found in two paintings of the crucifixion, designed by her court painter, Bernard van Orley ${ }^{74}$ In each painting, a portrait of Margaret of Austria in the guise of Caritas or "Charity" appears on the left side of Christ's cross. A personification of 'Justice' putting away her sword is shown on the opposite side. ${ }^{75}$ The concept of Margaret as Charity was devised by the regent in collaboration with her court artist with the aim of presenting herself as a benevolent and just ruler, who cared for the well-being of her people and her family like a mother. ${ }^{76}$

This analysis of Margaret's residence and her personal suite of rooms demonstrates that the floor plans and elevations contained no particular clues to the female gender of its occupant. The city of Mechelen built a palace befitting the governor-general and regent of the Burgundian-Habsburgian Netherlands, who happened to be a woman. Margaret was the first of a series of female regents who conscientiously represented the interests of the emperor in his Netherlandish provinces. Compared to the Coudenberg palace in Brussels, her 'Court of Savoy' in Mechelen was of moderate dimensions, but its original design still contained all the elements which were required for holding court as regent.

While gardens were constructed by men and women alike, the garden inside the 'Court of Savoy' can be described as a space which carried specific connotations for a female user. Its sheltered nature, closed off from the public life on the streets and places of the city of Mechelen, was ideally suited for those female occupants of her residence, who preferred the comparative privacy of the 'Court of Savoy'. The fact that Margaret established one of the first garden cabinets north of the Alps is striking. By placing a certain part of her collection, including her Naturalia, in a cabinet located on the ground floor, Margaret was able to create meaningful connections between her encyclopaedic collection and the garden as an artificially cultured and 
controlled piece of nature. ${ }^{7}$ This arrangement can be seen as one of the most modern features of her residence, which parallels the situation in Isabella d'Este's second apartment in Mantua.

Questions of gender come into play even more distinctly in the decoration of her library. Here Margaret made a gender-specific statement about her role as a loyal and devoted widow even as she exceeded this traditional image of dutiful woman in what she put on its shelves ${ }^{78}$ Margaret seems to have paid much more attention to the furnishing and maintenance of her residence than did her male relatives. This may partly be explained by the fact that she led a relatively stationary existence in comparison to her father, Maximilian I, and her nephew, Charles V, who constantly travelled from one end of their vast empire to the other. While Margaret's itinerary shows that she spent a reasonable amount of time each year outside the city of Mechelen, there is no indication that she transported all her movable possessions with her. ${ }^{79}$ Instead, she regarded the 'Court of Savoy' as her principal base and developed a strong interest in its meaningful decoration. In this regard Margaret's demeanour fits the parameters defined for women during the early modern period. In the public eye the life of a woman was closely tied to the house and was hence regarded as less dynamic and more static. ${ }^{80}$ Despite the fact that Margaret of Austria occupied an important public and political office and consequently had to fulfil many roles traditionally reserved for men, she nevertheless concentrated much of her energies on the interior of her residence as a publicly acknowledged female domain. This situation, which could be regarded by some as a limitation of her gender, was used by Margaret to her own advantage. By building up an important collection of artefacts and collectible items, Margaret developed a tool useful for conveying a range of messages to visiting dignitaries, local nobility and to the upper echelons of her household. The careful and intelligent way in which she orchestrated the distinctive displays in her library, her dining room, her bedroom and her cabinets allowed Margaret to make strong visual statements about herself and her dynasty. Even if the city had not provided all the comfort and luxury that Margaret had hoped for at the outset of her regency, she actively created an intellectual climate and generated cultural activities which compensated her for these shortcomings. Margaret's significant collecting activities and her patronage of the arts stimulated a wider interest in private collections amongst the local high nobility and prepared the ground for later generations of Habsburg collectors. Several characteristics of the so-called 'art and curiosity cabinet', usually seen as a product of the second half of the sixteenth century, can be traced back to Margaret's residence and collection in Mechelen. It was due to Margaret's tenacity and initiative that the 'Court of Savoy' in Mechelen was turned into one of the most important cultural centres within the Habsburgian empire and became a true focal point of female rulership. 


\section{Notes}

* I wish to thank the following friends and colleagues for their helpful comments on an earlier version of this chapter: Krista De Jonge, Catherine Kovesi, Markus Hörsch, Marie-Françoise Poiret and Charles Zika. Henri Installé gave generous assistance in my search for archival material. Wim Hüsken transcribed the Flemish sources, Thomas Bachmann provided several photographs (Figs 1.3, $1.5,1.6)$. The initial research for this project was made possible through grants provided by the Australian Research Council and the Deutsche Forschungsgemeinschaft.

For libraries and archival material, the following abbreviations have been used: Brussels, $A R=$ Brussels, Archives du Royaume de Belgique; Mechelen, StM = Mechelen, Stadsarchief; Lille, ADN = Lille, Archives Départementales du Nord, Chambre des Comptes; ÖNB = Vienna, Österreichische Nationalbibliothek; $\mathrm{BR}=$ Brussels, Bibliothèque Royale.

1. Wim Blockmans and Walter Prevenier, 'The second Flowering 1492-1530', in W. Blockmans and W. Prevenier, eds, The Promised Lands. The Low Countries under Burgundian Rule, 1369-1530 (Philadelphia: University of Pennsylvania Press, 1998), pp. 206-34.

2. After Margaret of Austria's death the regency was assumed by Mary of Hungary (1505-58), followed by Margaret of Parma (1522-86) and Isabella of Austria (1566-1633); sce M. Triest, Macht, vrouwen en politik 1477-1558. Maria van Bourgondië, Margareta van Oostenrijk, Maria van Hongarije (Leuven: Uitgeverij Van Halewyck, 2000); Luc Duerloo and Werner Thomas, Albrecht \& Isabella 1598-1621 (Turnhout: Brepols, 1998).

3. F. Steurs, Het Keizershof en het Hof van Margareta van Oostenrijk te Mechelen (Mechelen, 1879). The city of Mechelen and surrounding countryside formed part of Margaret's personal territories.

4. After 1506, many noblemen, courtiers and diplomats settled in Mechelen or erected grand residences; see M. Geys, 'Openbare Werken te Mechelen tijdens het bewind van Margaretha van Oostentijk (1507-1530), Proefschrift tot het verkrijgen van de graad van licenciate in de geschiedenis', unpublished M.A. thesis (Brussels, 1987).

5. In the annual accounts of the city of Mechelen, the residence is listed under a number of different names such as: hof van oesterijke or 'Court of Austria' $(1506 / 7)$, hof vanden keysere van rome or 'Court of the Emperor of Rome' (1507/8) and hof vanden keyser van hertoge kaerle or 'Court of the emperor and of Duke Charles' (1508/9).

6. Henri Installé, Historische Stedenatlas van België. Mechelen II (Mechelen: Handelingen van de Koninklijke Kring voor Oudheidkunde, Letteren en Kunst van Mechelen, 1997), p. 223. Over the following years the city purchased additional houses to close the remaining gaps in the precinct.

7. Ibid., pp. 31-5 and 132-4.

8. This plan was drawn up by the French government in the early nineteenth century with the intention of transforming the derelict building into a law court for the revolutionary forces.

9. The following account is a summary of my research on the residence and the collection of Margaret of Austria: D. Eichberger, 'Die Sammlung Margarete von Österreichs. Mäzenatentum, Sammelwesen und Kunstkennerschaft am "Hof van Savoyen" in Mecheln", unpublished Habilitationsschrift (Universität des 
Saarlandes, 1999), to be published as: Leben mit Kunst - Wirken durch Kunst. Sammelwesen und Hofkunst unter Margarete von Österreich, Regentin der Niederlande (London and Turnhout: Brepols, 2002); on the Keldermans see H. Janse, R. Meischke, H. v. Mosselveld and F. v. Tyghem, Keldermans: Een architectonisch netwerk in de Nederlanden (Den Haag: Staatsuitgeverij, 1987).

10. Brussels, AR, StM, 1517-18, fol. 230r, no. 5: 'Item Betaelt $\mathbf{M}^{\mathrm{r}}$. rombout Keldermans van zekere patronen te beworpenne der stad ende II den houe van my vrouwen van sauoeyen ae[n]gaende iij septembris - ij $f \mathrm{x} \mathrm{s}^{\mathrm{en}}$; this translates as: 'Item, paid Master Rombout Keldermans for designing several plans for the city and the court of Milady of Savoy'; 1519-20, fol. 229v; 1526-27, fol. 227r, no. 8 ; ibid., fol. $227 \mathrm{v}$, no. 12.

11. On the problems related to the reconstruction and the later additions, see Krista De Jonge, 'Une ouvre disparue de la Renaissance flamande dans une album de Du Cerceau: le portail d'entrée de l'Hôtel de Maximilien Transsylvanus à Bruxelles', Revue Belge d'Archéologie et d'Histoire de l'Art, LXVI, 1997, 75-105.

12. The section along Keizerstraat was drastically transformed by the far-reaching restoration campaigns of the late nineteenth century, Installe, Historische Stedenatlas, pp. 224-5.

13. M. Kocken, Mechelen volgens van den Eynde (Mechelen: Stevens, 1982). For a more detailed discussion of the reconstruction, see ch. II in Eichberger, 'Leben mit Kunst', pp. 58--86. The only room which I could not locate with certainty is Margaret of Austria's library.

14. Ordonnance of 3 April 1525, Brussels, AR, published in E. De Quinsonas, Materiaux pour servir à l'Histoire de Marguerite d'Autriche, Duchesse de Savoie, Régente des Pays-Bas (Paris: Delaroque Frères, 1860), vol, 3, pp. 281-90.

15. Room (B) is identical with the 'première chambre à chemynee', the first large chamber listed in the inventory of 1523-24. This document describes all those rooms occupied by Margaret of Austria which contained her movable objects apart from jewellery and clothing. Paris, Bibliothèque Nationale, Cinq Cents de Colbert 128 , published by M. Michelant, 'Inventaire des vaisselles, joyaux, peintures, manuscrits etc., de Marguerite d'Autriche, régente et gouvernante des Pays-Bas, dressé en son palais de Malines, le 9 juillet 1523', in Compte rendue des séances de la Comission royale d'histoire. Académie royale des Sciences, des Lettres et des Beaux-Arts de Belgique (Bruxelles), 3c serie, 12, 1871, 5-78 and $83-136$.

16. It can be assumed that this multifunctional space also served as an assembly room for the ducal household until the large hall $(\mathrm{K})$ was completed.

17. Dagmar Eichberger and Lisa Beaven, 'Family Members and Political Allies: The Portrait Gallery of Margaret of Austria in Mechelen', Art Bulletin, LXXVII (2), 1995, 225-48 and Eichberger, 'Leben mit Kunst' ch. II.

18. This space is called mij vrouwen camere or 'Milady's room' and mij vrouwen slaep cameren or 'Milady's bedroom' in the civic accounts. More information on this room and its decoration is provided in D. Eichberger, 'Female patronage in the light of dynastic ambitions and artistic quality', Oxford Journal of Renaissance Studies, 10 (2), 1996, 259-79 and 'Devotional Objects in Book Format: Diptychs in the Art Collection of Margaret of Austria and her Family', in Margaret Manion and Bernhard Muir, eds, The Art of the Book: Its Place in Medieval Worship (Exeter: Exeter University Press, 1998), pp. 285-303. 
19. Margaret's inventory for internal record keeping is kept in Paris, Bibliothèque Nationale, Cinq Cents de Colbert 128, fol. 80r: [1523-24] Aultres meubles estans dedans le petit cabinet joignent la chambre a chemynée tirant sur la gallerie de la chapelle.

20. In 1523-24 the city silversmith is paid for some repairs at "the porch where she listens to mass' (int poortael daer zij misse doer hoort), see Brussels, AR, StM, 1523-24, fol. $210 \mathrm{r}$, no. 2.

21. H. Lickes, "Chorflankierende Oratorien und Herrschaftslogen des späteren Mittelalters", unpublished Ph.D. thesis (Eberhard-Karls-Universität Tübingen, 1982). The best-preserved example is the private oratory of the Gruuthuse family in Bruges; see M. P. M. Martens, Lodewijk van Gruuthuse. Mecenas en Europees Diplomaat ca. 1427-1492 (Brïgge: Stichting Kunstboek, 1992).

22. The church of Saint Peter and the wooden walkway were destroyed in the late eighteenth century.

23. Brussels, AR, StM, 1525-26, fol. 201v, no. 3 .

24. Margaret's valuable tapestries were probably kept either in this room or in the equivalent room on the ground floor.

25. Brussels, AR, StM, 1523-24, fol. 210r, no. 2. There may have been another doorway connecting the bedroom directly with the dressing room.

26. The ciel of the baldachin measured 120.6 by $86.2 \mathrm{~cm}$. Room (D) is the most likely candidate for this cabinet as it could be accessed both from the large hall and from the dining hall. The contents of this cabinet are described immediately after the description of the première chambre and before the section on the seconde chambre.

27. Eichberger, 'Leben mit Kunst', ch. III and C. L. Ishikawa, 'The "Retablo de la Reina Catolica" by Juan de Flandes', unpublished dissertation (Philadelphia, Bryn Mawr College, 1989).

28. These scenes are: The penitence of Mary Magdalene, Christ and the Woman with the Issue of Blood, Christ and the Woman of Samaria, The Resurrection of Lazarus, Three Maries at the Tomb, Noli me Tangere; see Eichberger, 'Leben mit Kunst', ch. IV, pp. $234-48$.

29. Paris, B.N., Cinq Cents de Colbert 128: the general heading for this room on fol. 89r is: Bacgues, menutez de vaicelles, estans au cabinet emprès le jardin ou sont les coraulx, le tous d'argent; on fol. $102 \mathrm{r}$ a sub-section within the same cabinet carries the heading: Aultres menutez estans au petit cabinet ou sont les coraulx et jardin de fleurs de soie, fil d'or et autres choses fait d̀ l'esgulle, dont s'ensuyt, pièces y estant d'argent. Margaret kept more than 60 objects made from or with silver in this particular room.

30. Within the limits of this chapter I will only touch upon certain aspects of the garden cabinet; see Eichberger, 'Leben mit Kunst', ch. VII.

31. Jean Lemaire, La Couronne Margaritique, Vienna, O.N., Cod. 3441, 1504-5, see Marguerite Debae, La bibliothèque de Marguerite d'Autriche: essai de reconstruction d'après l'inventaire de 1523-24 (Louvain and Paris: Peeters, 1995), cat. no. 374, pp. 504-7.

32. M. M. Fontaine, 'Lemaire de Belges', in J. P. de Beaumarchais, D. Conty and A. Roy, eds, Dictionnaire des Littératures de Langue Française (Paris: Bordas, 1994), pp. 1367-9.

33. In Margaret's household inventory, the description of this small room on the ground floor follows on immediately from the section dedicated to the regent's study. Eichberger, 'Leben mit Kunst', ch. VII. 
34. Her most important painting in this cabinet was Jan Gossaert's Hermaphroditus and Salamacis. It shows the Nymph Salamacis violently embracing the object of her desire, the boy Hermaphroditus. This theme fits very well into the context of garden and nature. F. Lammerste, ed., Van Eyck to Bruegel. 1400-1550. Dutch and Flemish painting in the collection of the Museum Boymans-van Beuningen (Rotterdam: Museum Boymans-van-Beuningen, 1994), cat. no. 36, pp. 174-9.

35. In contrast to medieval collections, Margaret kept a considerable amount of natural objects in their natural state and did not use them as raw material for jewellery or reliquary containers. This suggests a proto-scientific interest in substances such as gems, precious stones and so on.

36. W. Liebenwein, Studiolo. Zur Entstehung eines Raumtyps und seiner Entwicklung (Berlin: Mann, 1977), chs III and IV, pp. 74ff; E. Bergvelt, D. J. Meijers and M. Rijnders, eds, Verzamelen. Van Rariteitenkabinet tot Kunstmuseum (Heerlen: Gaarde Uitgevers, 1993), pp. 18-26.

37. K. Pomian, 'Sammlungen - eine historische Typologie', in A. Grote, ed., Macrocosmos in Microcosmos. Die Welt in der Stube. Zur Geschichte des Sammelns, 1450-1800 (Opladen: Leske + Budrich, 1994), pp. 112-13. Only in the second half of the sixteenth century are the various categories of collecting defined in theoretical treatises; see H. Roth, Der Anfang der Museumslehre in Deutschland. Das Traktat 'Inscriptiones vel Tituli Theatri Amplissimi' von Samuel Quiccheberg (Berlin: Akademie Verlag, 2000); for Naturalia see pp. 55-61 and 238-41.

38. Published by J. Stecher, ed., Euvres de Jean Lemaire de Belges (Louvain: De J. Lefever, 1891), vol. 4, pp. 10-167. Marie-Madeleine Fontaine and Hélène Naïs are preparing a new edition of this important manuscript.

39. According to Lemaire the term Gorgonia is used by Pliny in his Historia Naturalis;, see Stecher, Euvres, vol. 4, p. 84.

40. Eichberger, 'Leben mit Kunst', ch. VI, pp. 1350-53.

41. Brussels, AR, StM, 1515-16, fol. 230v, no. 6; ibid., 1516-17, fol. 219v, no. 4; fol. 233r, no. 3; ibid., 1517-18, fol. 226r, no. 4; ibid., 1518-19, fol. 234r, no. 4; ibid., 1521-22, fol. 233v, no. 3; see also Brussels, AR, Acquits de Lille, no. 524 VIII, as quoted in Ghislaine De Boom, Marguerite d'Autriche-Savoie et la PréRenaissance (Brussels: Droz + Falk Fils, 1935), p. 130, fn. 1. At the beginning of the nineteenth century the southern half of the courtyard was closed off by a high wall which created a much more sheltered terrain than exists nowadays.

42. J. Guillaume, 'Château, jardin, paysage en France du XV' au XVII' siècle', Revue de l'Art, 124, 1999, 13-32. The development of the Renaissance garden with its complex internal structures reflects a basic change in the way nature was perceived by humankind.

43. For recent research on this topic, see J. Guillaume, ed., Architecture, Jardin, Paysage. L'environement du château et de la villa aux XVe et XVle siècles (Paris: Picard, 1999).

44. Brussels, B.R., Ms. II158, fol. 3v, c. 1530, attributed to Simon Bening; see W. Prevenier, Le prince et le peuple. Images de la societé du temps des ducs de Bourgogne 1384-1530 (Antwerpen: Mercatorfonds, 1998), pp. 133-4; see also R. De Herdt, Tuinen van Eden, Van Keizer Karel tot heden (Ghent: Museum voor Industriele Archeologie en Textiel, 2000), pp. 12-23 and 84-5.

45. Vienna, Ö.N., Cod. 2627, Provence, c. 1460; see Debae, La bibliothèque de Marguerite d'Autriche, no. 370, pp. 495-8 and F. Brachert, ed., Von Minne, 
Kampf und Leidenschaft. Die Bilder der Wiener Théséide (Graz: Akademische Druck und Verlagsanstalt, 1989).

46. There are, for instance, an arcade made from bluestone, a stepped gable built from brick and large square-shaped windows with mullion and transom.

47. De Herdt, Tuinen van Eden, pp. 13-15; see also John Harvey, Mediaeval Gardens (London: Batsford, 1981), pp. 13443 and G. Venturi, 'Der "Giardino Segreto" der Renaissance: Ursprung und Entwicklung', in M. Mosser and G. Teyssot, eds, Die Gartenkunst des Abendlandes von der Renaissance bis zur Gegenwart (Stuttgart: Deutsche Verlagsanstalt, 1993), pp. 84-6.

48. Juan Luis Vives, The Education of a Christian Woman: a sixteenth-century manual, edited and translated by Charles Fantazzi (Chicago: The University of Chicago Press, 2000).

49. De Quinsonas, Materiaux pour servir à l'Histoire de Marguerite d'Autriche, vol. 3, p. 289: 'un cheval deffroié quand Madame yra par les champs seullement'.

50. See D. Eichberger, 'A Renaissance Princess Named Margaret. Fashioning a Public Image in a Courtly Society', Melbourne Art Journal, 4, 2001. On this aspect of gender also see $\mathrm{S}$. Bertière, 'Regence et pouvoir féminin', in $\mathrm{K}$. Wilson-Chevalier and E. Viennot, eds, Royaume de Fémynie. Pouvoir, contraintes, espaces de liberté des femmes, de la Renaissance à la Fronde (Paris: Honore Champion, 1999), p. 69.

51. Liebenwein, Studiolo, pp. 108-13.

52. Krista De Jonge, "Der herzogliche und kaiserliche Palast zu Brïssel und die Entwicklung des höfischen Zeremoniells im 16. und 17. Jahrhundert', Jahrbuch des Zentralinstituts für Kunstgeschichte, V/VI, 1989/90, especially 269-71; K. De Jonge, 'Het paleis op de Coudenberg te Brussel in de vijftiende Eeuw. De verdwenen hertogelijke Residenties in de zuidelijke Nederlanden in een nieuw Licht geplaatst', Revue Belge d'Archéologie et d'Histoire de l'Art, LLX, 1990 , 5-38; K. De Jonge, 'Le palais de Charles-Quint à Bruxelles', in Jean Guillaume, ed., Architecture et Vie Sociale. L'organisation des grandes demeures d̀ la fin du Moyen Age et d la Renaissance, Bd. 1 (Paris: Picard, 1994), pp. 107-25.

53. W. Paravicini, 'The Court of the Burgundian Dukes of Burgundy: A Model for Europe?', in R. G. Asch and A. M. Birke, eds, Princes, patronage and the nobility. The court at the beginning of the modern age, c. 1450-1650 (Oxford: German Historical Institute, 1999), pp. 69-102, and H. Kruse and W. Paravicini, eds, Höfe und Hofordnungen 1200-1600 (Sigmaringen: Thorbecke, 1999).

54. These are, however, only two of several factors which have to be taken into account when judging the relative size and comfort of an apartment. The financial means of the host and the structure of the residence may have determined equally the degree of comfort which was provided.

55. De Jonge, 'Le palais', p. 107.

56. M.-F. Poiret, Le Monastère de Brou. Le chef-d'oeuvre d'une fille d'empereur (Paris CNRS Editions, 1994), p. 8.

57. It was also possible to reach each room via the gallery.

58. The room is described in more detail in a manuscript dating from the late seventeenth century, which was written by a prior from the Augustinian monastery in Brou; Père Raphaël de la Vierge Marie, 'Description historique de la Belle Eglise et du couvent Royal de Brou tiree de leurs archives et des meilleurs historiens qui en ont ecrit', unpublished manuscript owned by the Societé d'Emulation de l'Ain, p. 120: 'et l'autre d'une partie de la salle de la Princesse éclairée de ce côté là par six croisées de fenétres [...]'. I wish to thank 
Marie-Françoise Poiret, Musée de Brou, for providing the information on Père Raphaël. The unfinished large hall in Mechelen also had six window bays.

59. It is not clear whether this cabinet was destined to be Margaret's study or whether it was meant to fulfil another function.

60. In later years her plans changed and she intended to move into a house located next to the Annonciade monastery in Bruges. Margaret was one of the main patrons of this female convent.

61. On this note see W. Cahn, 'Towards the enduring monument: Nantes, Brou, Margaret of Austria', in Masterpieces. Chapters in the History of an Idea (Princeton: Princeton University Press, 1979), pp.43-64 and T. Tolley, 'States of independence: women regents as patrons of the visual arts in Renaissance France', Renaissance Studies, 10, 1996, 237-58.

62. Poiret, Le Monastère de Brou, p. 75: "sepultures si riches et sumptueuses comme telz prince et princesse appartient'.

63. 'The greatest masterpiece that is going to be made in this part of the country', ibid., pp. 72 and 75.

64. Père Raphaël, 'Description historique', pp. 116-17: 'elle pouvait aller directement à plain pied et à couvert, de ses chambres à son oratoire dans l'église, en cette salle dont nous avons parlé (une des plus grandes qu'on voit dans les provinces)'. In the margins, the measurements are given: 'longueur de la sale 87 piés et demi, largeur 27 piés et demi'.

65. I am grateful to Krista De Jonge, who drew my attention to this link and pointed to the examples listed here; as reference see F. Chueca Goitia, Casas Reales en monasterios y conventos españoles (Madrid: Real Academia de la Historia, 1966).

66. Ibid., p. 133.

67. This may also explain why visual references to Margaret are less conspicuous in Mechelen than in her funerary church in Brou. There was only one single portrait of her in the more public sections of her residence, compared to multiple portraits of Maximilian I and Charles V. See Eichberger, 'Female patronage'.

68. The Italian quote reads: 'Lli te Mechelen se vedde la casa di madamma Margarita, quale è molto bella et assai in ordine, benchè non di molta vista, dove è una libraria per donne assai ornata et riccha $[\ldots]$ Et vi sono de belle tavole et altre picture de diverse et tucte bone mane. Et di marmore vi sono le teste del duca di Savoya di fe. me. suo marito, che mostra essere stato bellissimo giovene como dicono che era, et de sua S. illma quando era jovenecta con molto artificio facte et secondo la relatione naturalissime', in L. Pastor, Die Reise des Luigi d'Aragona ...1517-8, beschrieben von Antonio de Beatis (Freiburg im Breisgau: Herder, 1905), p. 115.

69. This matter is discussed in more detail in Eichberger, 'Die Sammlung'.

70. Lille, ADN, B 3513 [1516], 'L'epitaphe du Philibert de Savoy, second de son nom, sur ung petit tableaul de bois', quoted from J. Finot, Inventaire sommaire des Archives Départmentales antérieures à 1790 (Lille: L. Danel, 1895), p. 236.

71. Philibert's social standing was not quite as high as that of Margaret's first two partners, Charles VIII and Juan of Castille, but he still belonged to one of the leading noble families in France. His sister, Louise of Savoy, had married into the French royal family and was most influential as regent and mother of the new king, Francis I.

72. Vienna, Kunsthistorisches Museum, Kunstkammer, Inv. Nr. 3150: 'MARGARETA CESA[R]UM AUSTRIIA]E UNICA FILIA ET AMITA 1528'; for further information see Eichberger, 'A Renaissance Princess'. 
73. Jean Franco, Généalogie abrégée de Charles Quint, Paris, B.N., ms.fr. 5616, c. 1527, see Debae, La bibliothèque de Marguerite d'Autriche, cat. no. 356, pp. $490-2$.

74. These paintings were not kept in her residence; however, a similar iconography was used for her state baldachin; see Eichberger, 'A Renaissance Princess', pp. $19-22$.

75. Bernard van Orley and workshop, 'Allegorical crucifixion with Caritas and Iustitia', after 1524, Rotterdam, Museum Boymans Van Beuningen; see Lammertse, Van Eyck to Bruegel, cat. no. 37, pp. 180-3.

76. See Eichberger, 'A Renaissance Princess'.

77. Here it is worthwhile to mention again (see note 34) the important painting by Gossaert of the Nymph Salamacis embracing her object of desire, Hermaphroditus, in a pond (Rotterdam, Museum Boijmans Van Beuningen). This theme fits very well into the context of garden and nature.

78. The bedroom was a further area within the residence in which Margaret attempted to demonstrate female virtues via her collection of artefacts and devotionalia.

79. See M. Bruchet and E. Lancien, Itinéraire de Marguerite d'Autriche, gouvernante des Pays-Bas (Lille: Max Pierre Movie, 1934).

80. Mark Wigley, 'Untitled: The Housing of Gender', in B. Colomina, ed., Sexuality and Space (Princeton: Princeton Architectural Press, 1992), pp. 326-51; L. Roper, 'Tokens of affection: the meaning of love in sixteenth-century Germany', in Dagmar Eichberger and Charles Zika, eds, Dürer and his Culture (Cambridge: Cambridge University Press, 1998), pp. 143-63. 


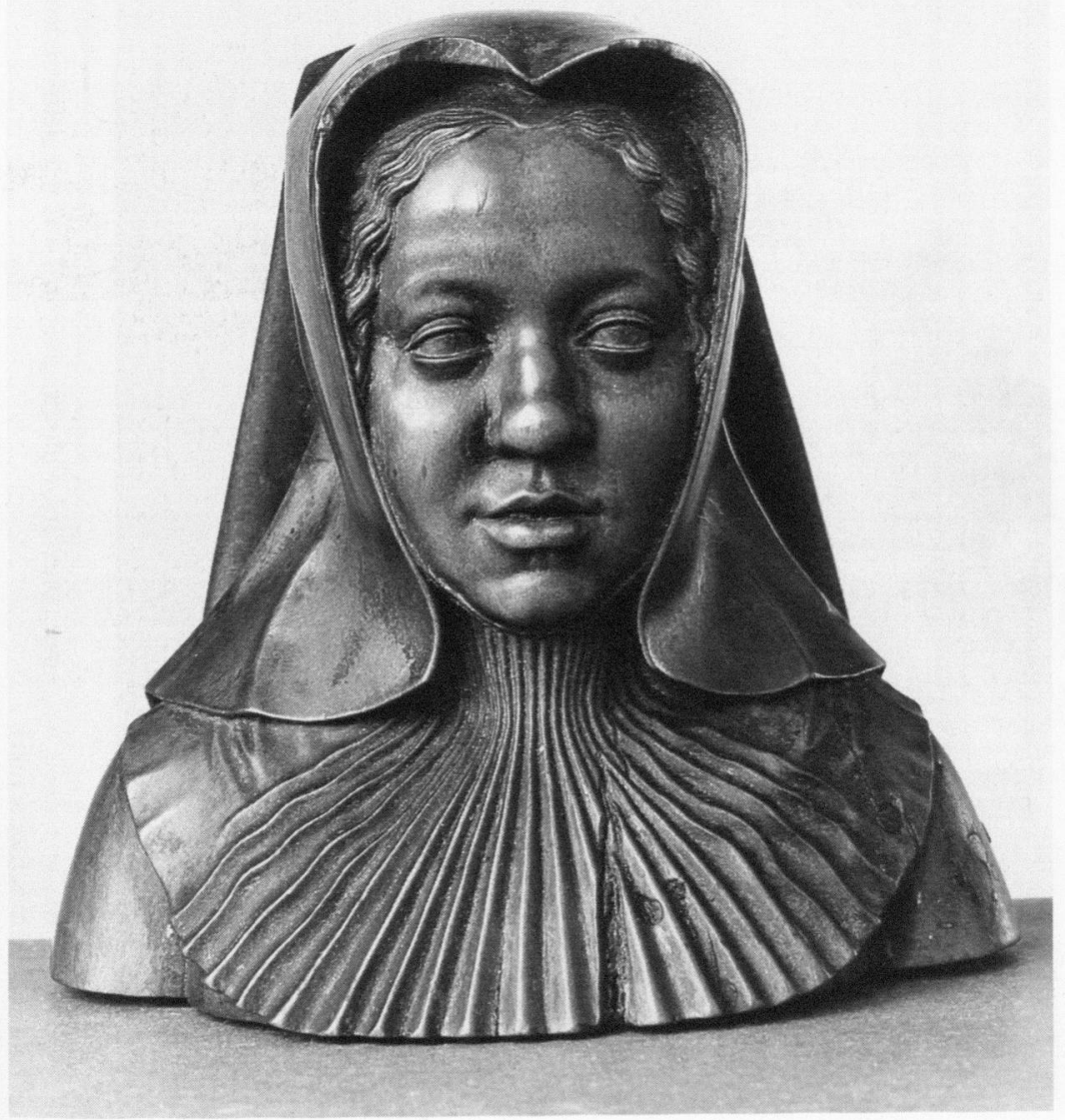

Fig. 1.1: Conrat Meit, Margaret of Austria as a widow, pear wood sculpture, $7.4 \mathrm{~cm}$, circa 1518, Munich, Bayrisches Nationalmuseum (R 420) (Photo: (C) Munich, Bayrisches Nationalmuseum) 


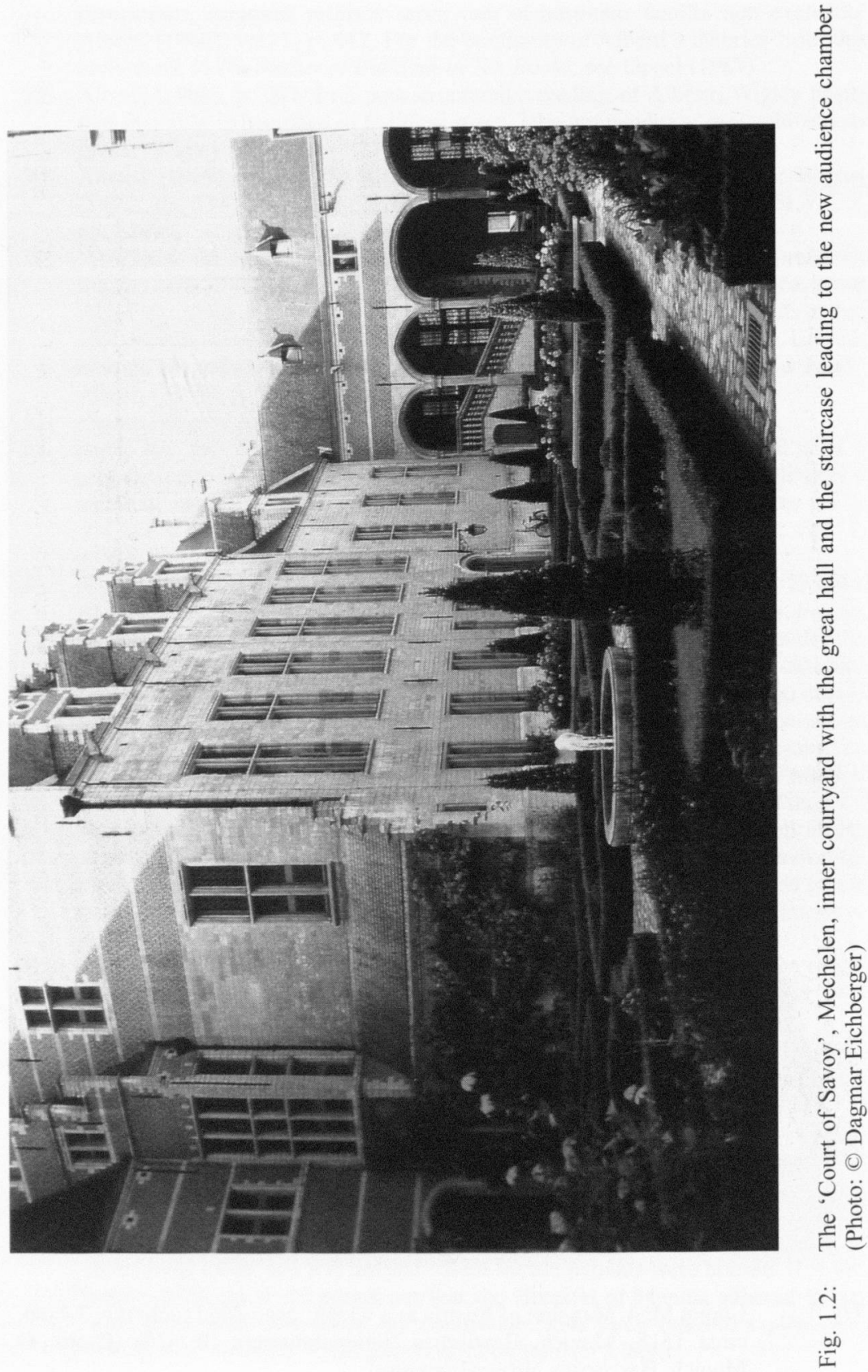




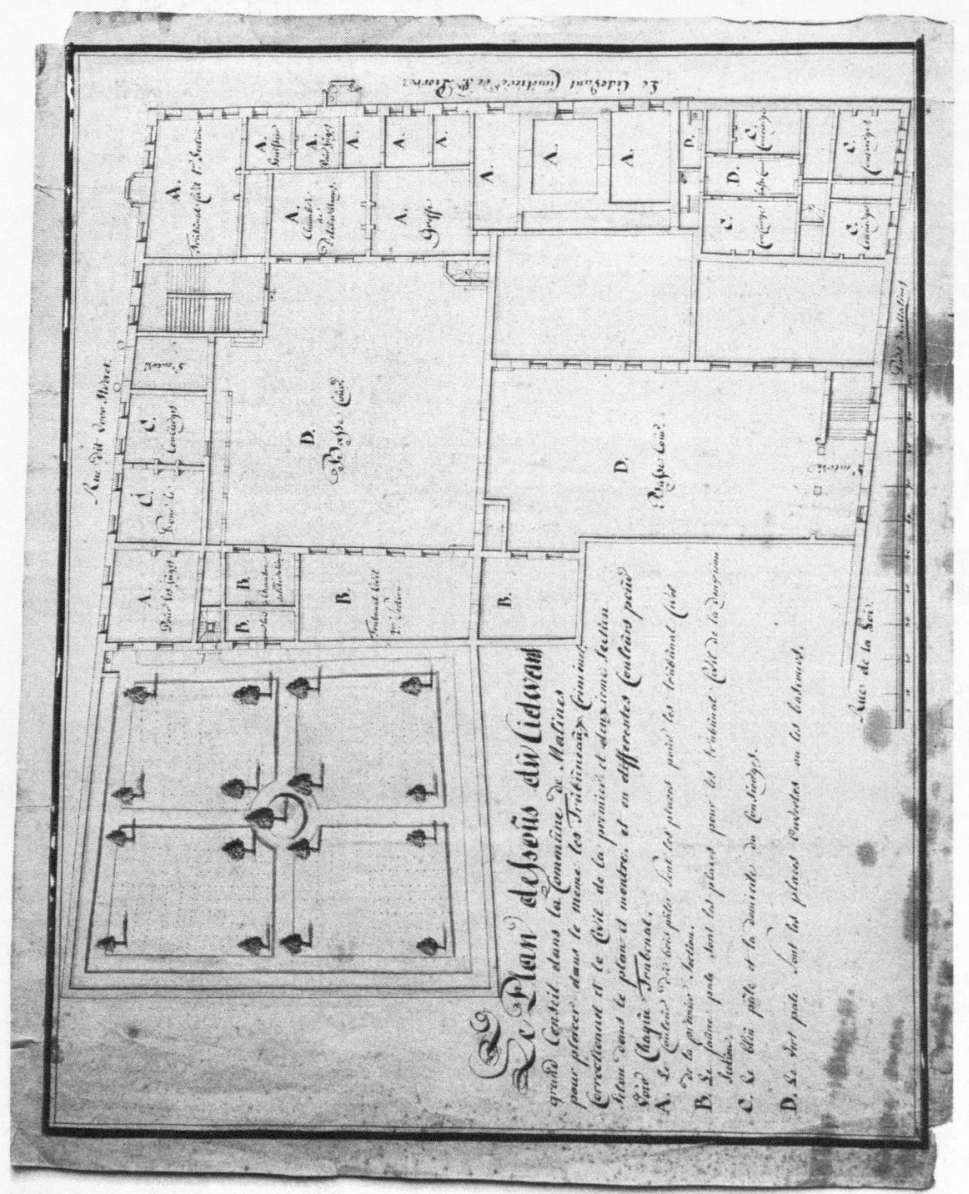

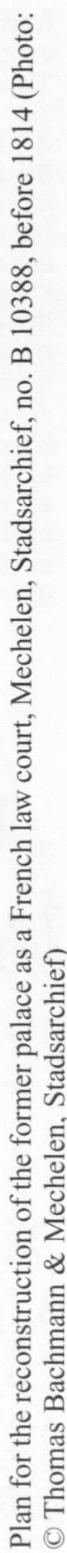


Reconstruction of Margaret of Austria's living quarters on the first floor of the 'Court of Savoy' in Mechelen
A) chappelle
B) première chambre à chemynée
C) seconde chambre à chemynée
D) riche cabinet
E) petit cabinet
F) garderobbe
G) gallerie de la chappelle
H) treasury
I) access to the spiral staircase
J) access to the spiral staircase
K) great hall
L) large audience chamber
a) southern entrance
b) large staircase
c) courtyard with garden
d) northern staircase
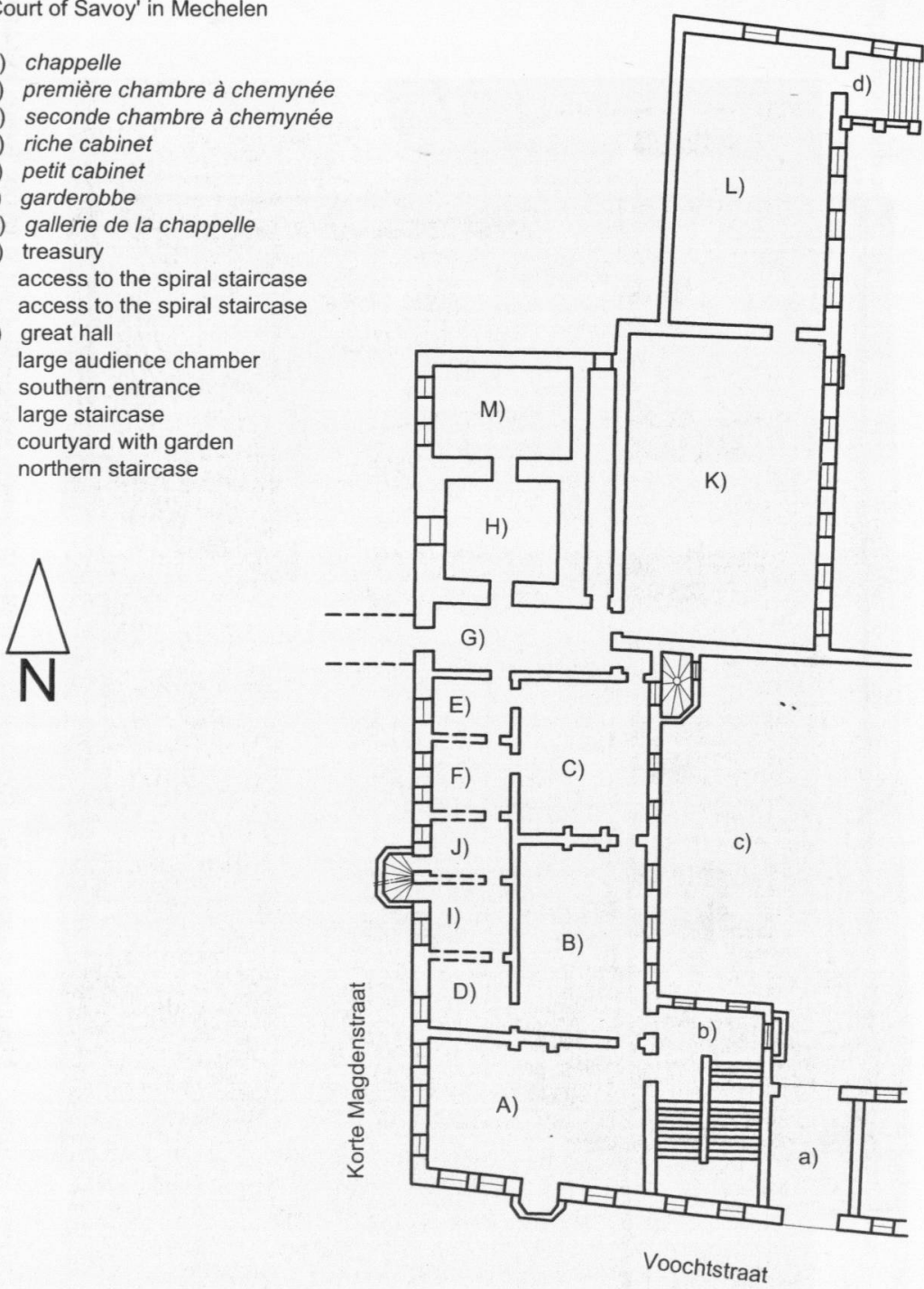

Fig. 1.4: Reconstruction of Margaret's former apartments on the first floor of the western wing of the 'Court of Savoy', Mechelen (Reconstruction: (C) Dagmar Eichberger) 


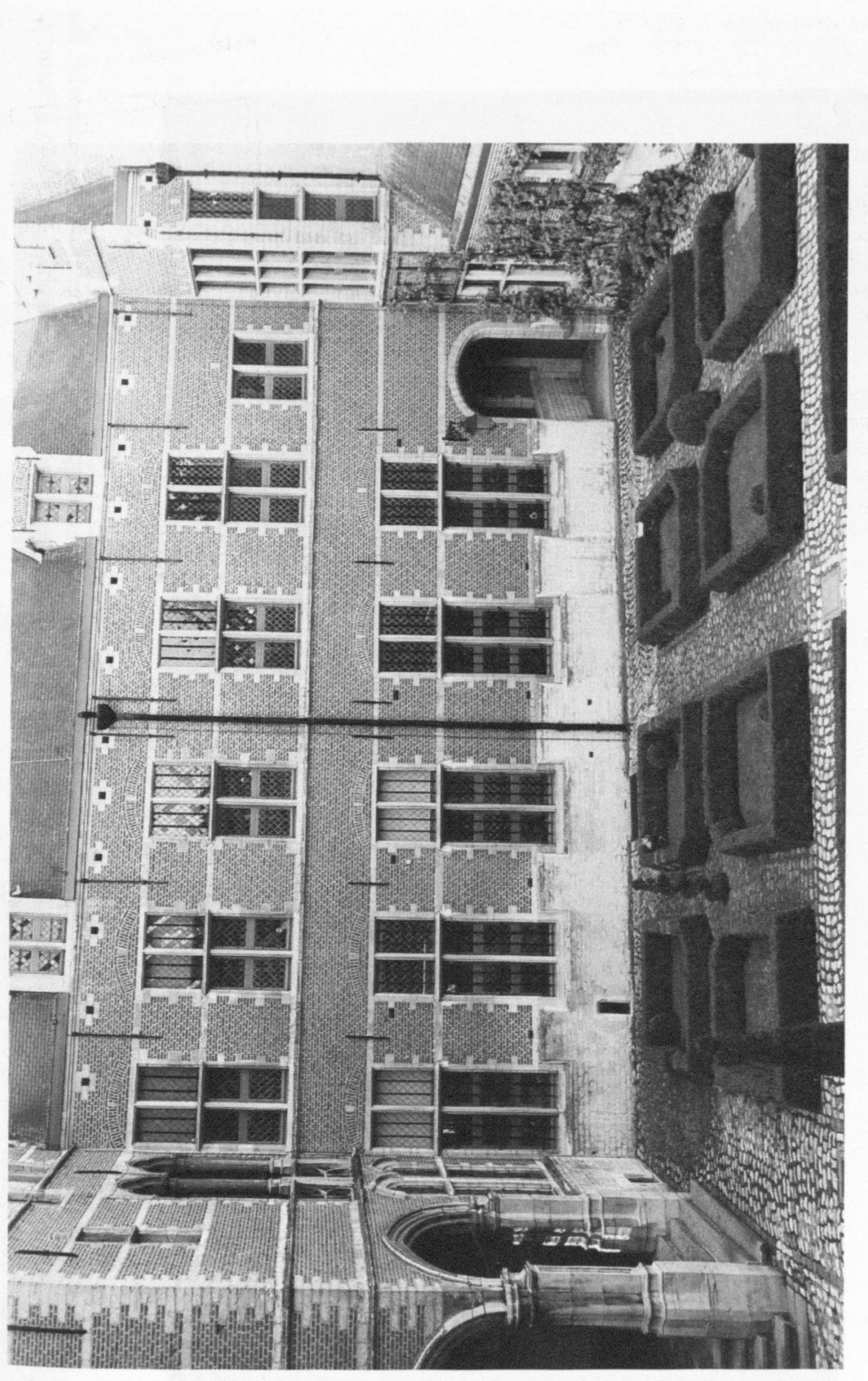

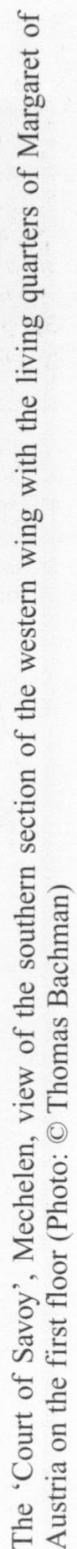




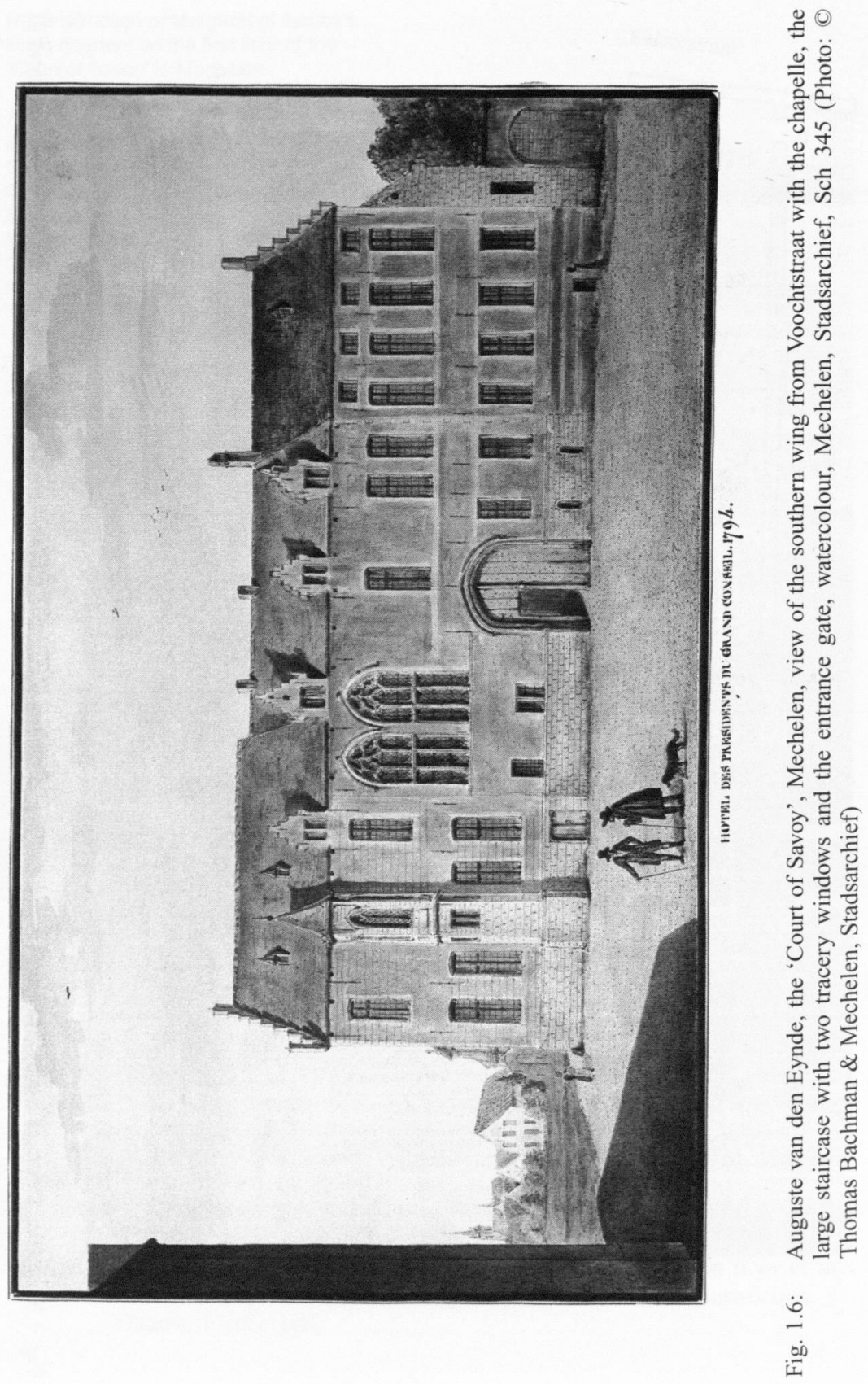




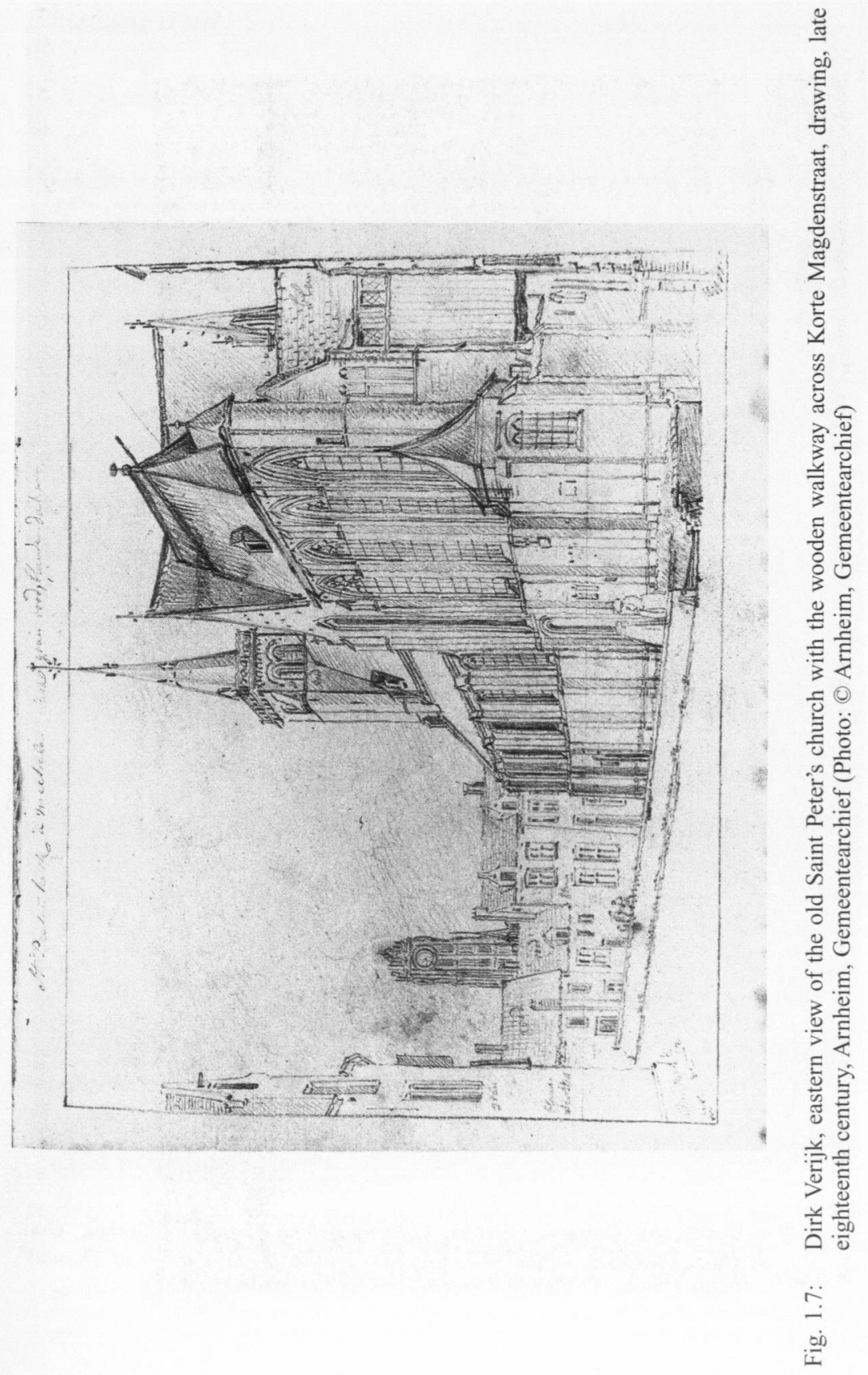



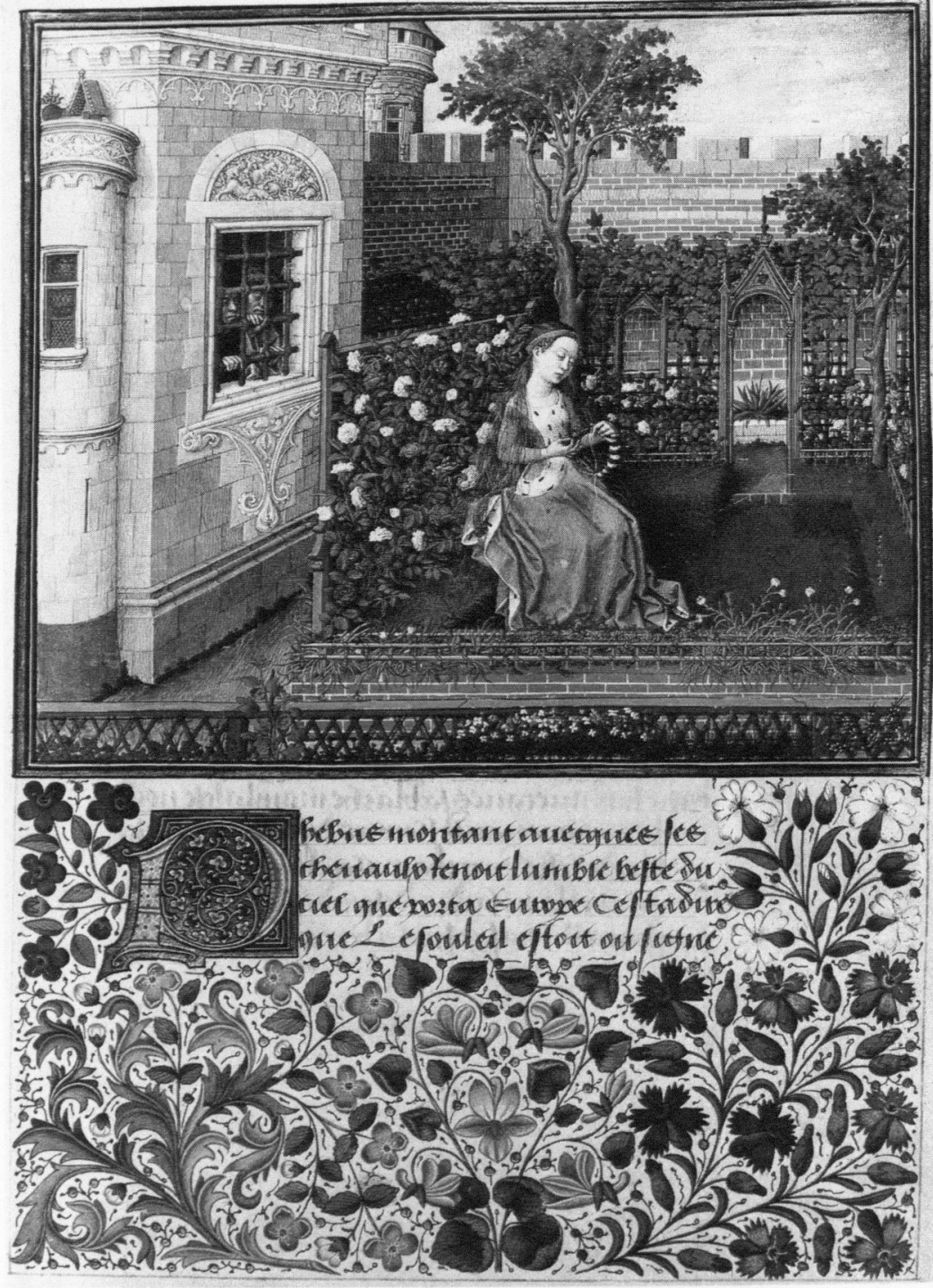

Fig. 1.8: Boccaccio, Theseida, Vienna, Österreichische Nationalbibliothek, Cod. 2627, Provence, circa 1460, fol. 53r: Emilia in the garden of Theseus' castle (Photo: (C) Vienna, Österreichische Nationalbibliothek) 


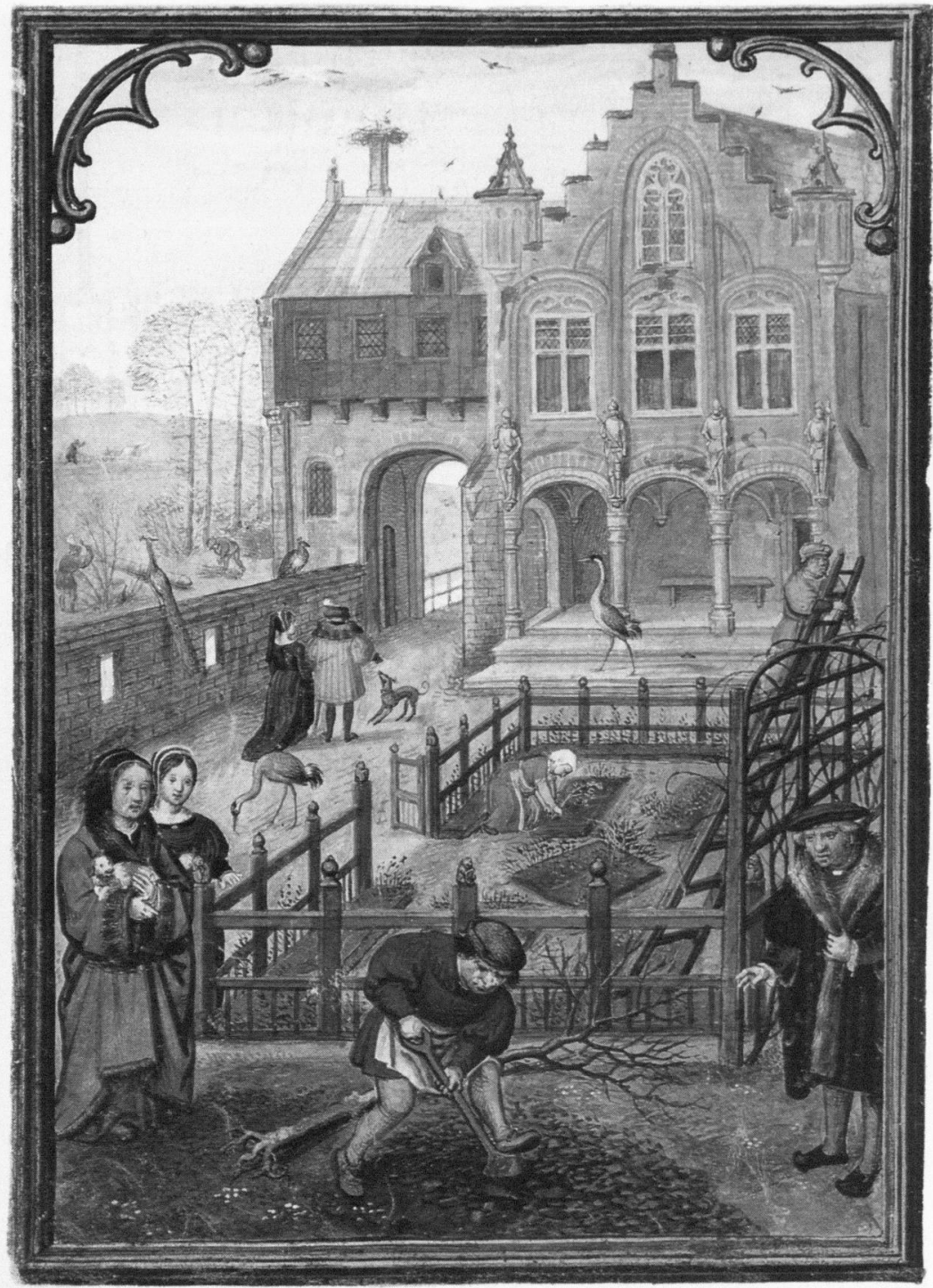

Fig. 1.9: Hennessy Hours, Brussels, Bibliothèque Royale d'Albert, ms. II 158, southern Netherlandish, early sixteenth century, fol. 3v: View of a Flemish residence with garden (Photo: (C) Brussels, Bibliothèque Royale de Belgique) 

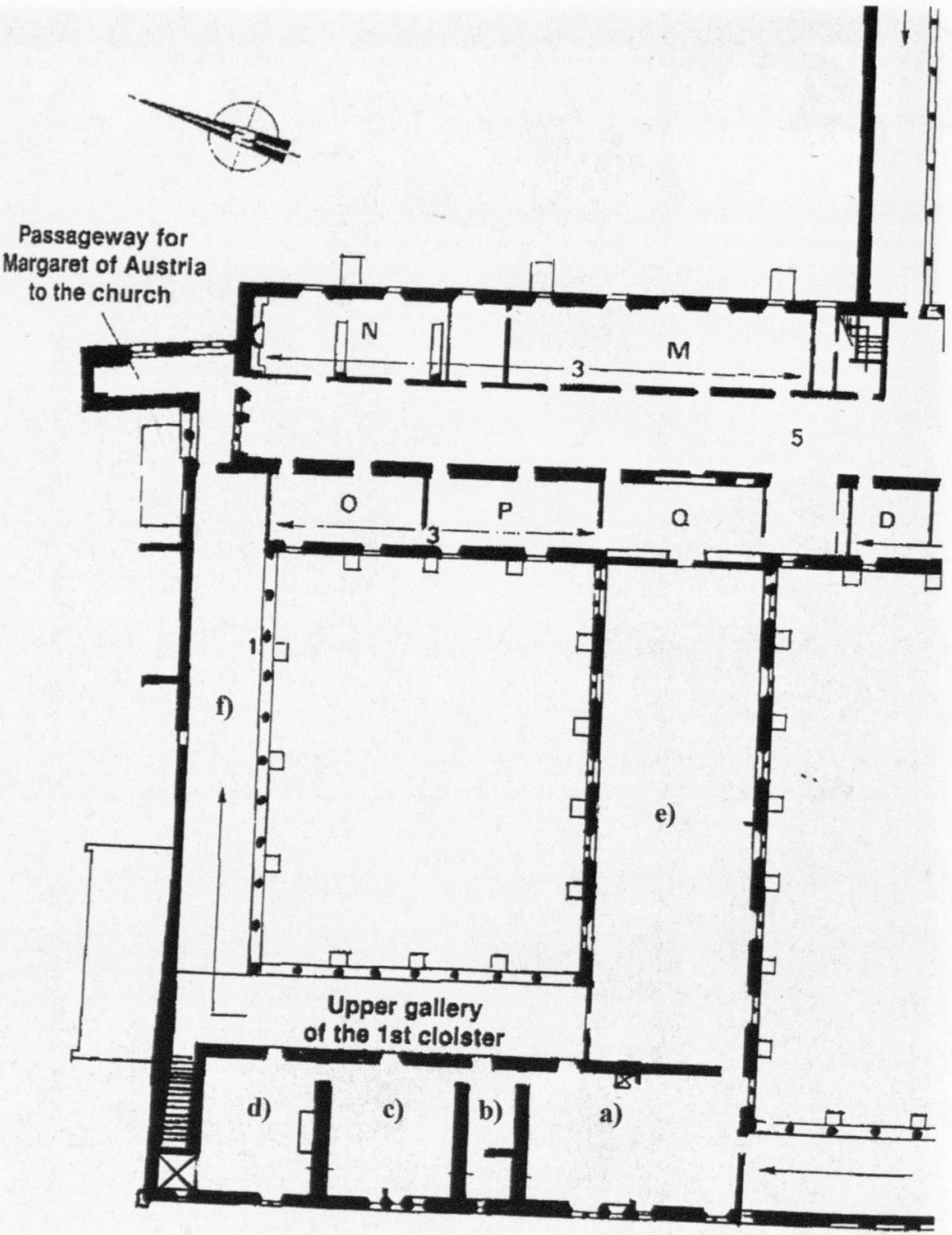

Fig. 1.10: Brou, Augustinian monastery, Margaret of Austria's living quarters on the first floor of the northern cloister (Photo: (C) Bourg-en-Bresse, Musée de l'Ain) 


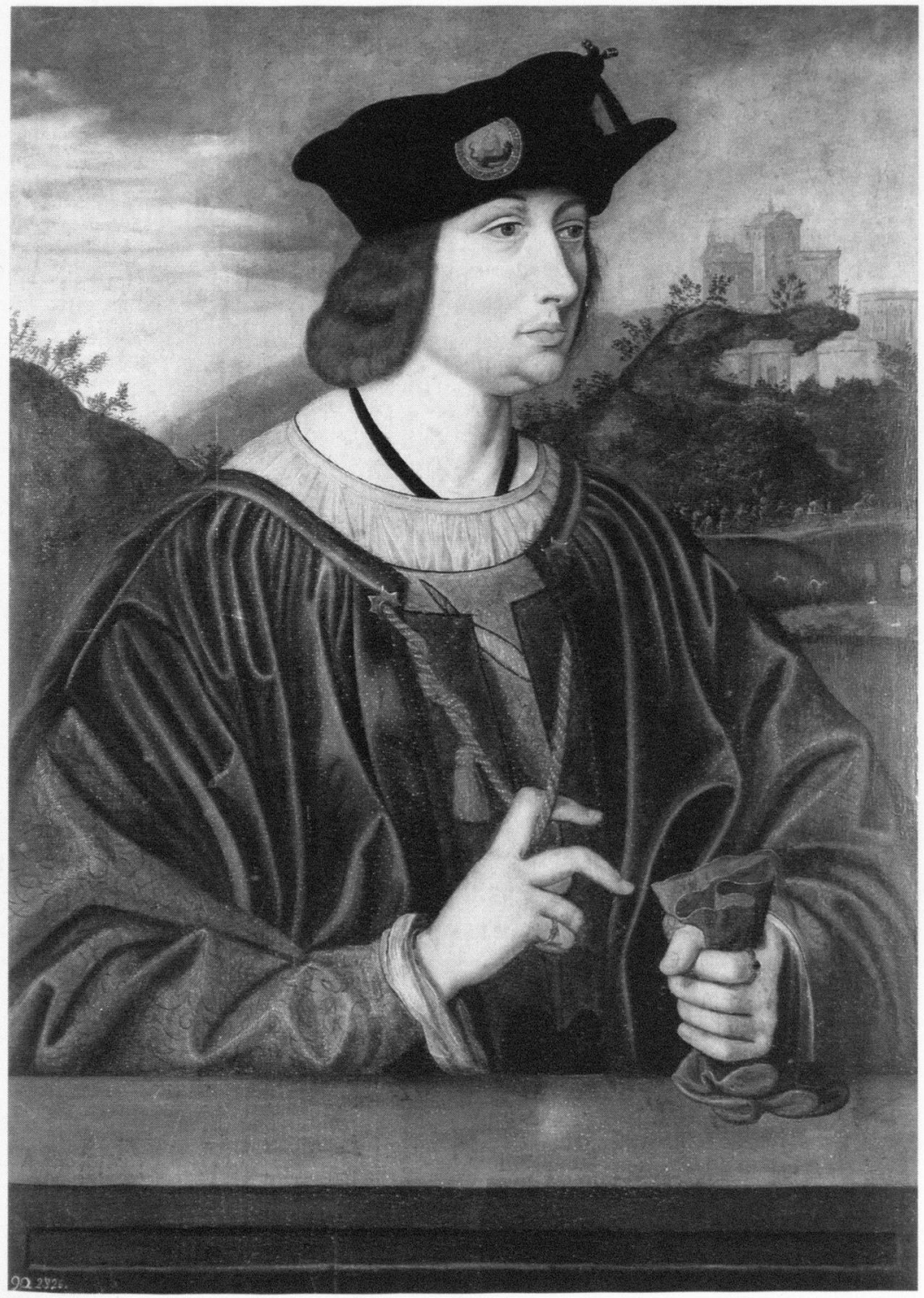

Fig. 1.11: Jan Mostaert, Philibert of Savoy, oil on wood, Madrid, Prado (Photo: C) Madrid, Prado) 